This is an open access article under the CC BY-NC-ND license

Issue IV, 22 November 2021

e-ISSN 2707-9481

Institute of Metallurgy and Ore Beneficiation, Satbayev University, Almaty, Kazakhstan

ISBN 978-601-323-252-2 https://doi.org/10.31643/2021.19

\author{
Hendri Pratama * \\ Faculty Technical and Vocational, Sultan Idris Education \\ University, Tanjong Malim Perak, Malaysia. \\ Email: hendripratama.tvet@gmail.com \\ ORCID ID: 0000-0002-0985-8156
}

Mohamed N. A. Azman

Faculty of Technical and Vocational, Sultan Idris

Education University, Tanjung Malim, Perak, Malaysia

Email: mnazhari@ftv.upsi.edu.my

ORCID ID: 0000-0003-1756-1990

\section{Nor Asimah Zakaria}

Faculty of Technical and Vocational, Sultan Idris Education University, Tanjung Malim, Perak, Malaysia Email: zsyimah@ftv.upsi.edu.my ORCID ID: 0000-0002-8888-3981

\author{
Moh Khairudin \\ Faculty of Technical, Yogyakarta State University, \\ Special Region of Yogyakarta 55281, Indonesia, \\ Email: moh_khairudin@uny.ac.id \\ ORCID ID: 0000-0003-0817-2061
}

\title{
Development of programmable logic controller teaching aids on electrical motor installation course among vocational school students in Aceh, Indonesia
}

\begin{abstract}
Programmable Logic Controller (PLC) is a competency that must be mastered by third-level vocational school students in an electrical motor installation course. PLCs can be operated using programming languages such as sequence function charts, block diagrams, instruction lists, ladder diagrams, and others. This competency is important because it is often used in the industrial world. To create better and more effective conditions in the teaching and learning process, the development of teaching aids is needed to improve and enhance students' skills. This research, to design and development a useful teaching and learning tool teaching medium to help teachers teach concepts PLC-based electrical control systems, both theoretically and practically. The ADDIE model was used in developing the aids. The verification stage is carried out to ensure that the teaching aids that have been developed are suitable for use. In addition, this kit is relatively small with dimensions of $45 \times 34 \times 20 \mathrm{~mm}$ and is easy to move and can be used in various places. Confirmation involves lecturers and teachers who teach the field of electrical engineering. The results of the study found that the respondents strongly agreed that the PLC teaching aids was suitable for use in the learning process. Respondents also stated that using the tool because did not waste time and was easy to use. However, it is suggested that further research be conducted to identify the effectiveness of this teaching aid on students.
\end{abstract}

Keywords: development, teaching aids, PLC, ADDIE, vocational students.

Cite this article as: Pratama, H.; Azman, M.N.A.; Zakaria, N.A.; Khairudin, M. (2021). Development of programmable logic controller teaching aids on electrical motor installation course among vocational school students in Aceh, Indonesia. Challenges of Science. Issue IV, pp. 117-127. https://doi.org/10.31643/2021.19

\section{Introduction}

Currently, the industrial fields have entered the era of automation, and the use of automated control systems has simplified the entire construction process. The machines are now operated by a computer control system commonly called Programmable Logic Controller (PLC) [1]. In the Curriculum 2013, the current range of skills has been tailored to the needs of the course, knowledge development, technology and the world of work. One of the professional fields of the vocational school is the field of electrical engineering, which is a type of interest skills. It contains PLC competency standards for form 3 students vocational school. PLC can be used in various forms of instructions developed by programmers. PLC is a single computer-based processor device that needs to be scrutinized in vocational school 
institutions (Figure 1). PLC is a very widely used control system in the industry. PLC can be defined as a controller component consisting of input signals and output signals, and programs that are provided to the PLC to run or control machines organized by programmers. Programming control PLC analyzes input signals and sets the state of the output signals according to the program written by the user.

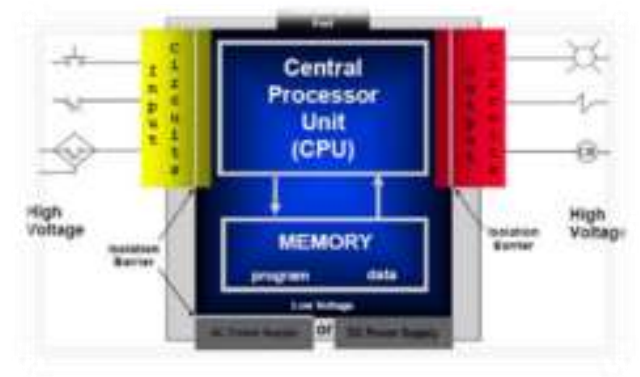

Figure 1 - The fundamental of PLC system

To train students with PLC tool application skills, in-depth knowledge and skills are of paramount importance. The mastery of vocational students on PLC programming theory is still very low. This is because it is easier for them to understand the curriculum through direct practice than to only theoretically understand it (Abdullah et al., 2010). Proficiency in PLC programming is a skill that every student must possess in electrical engineering, especially when exploring the field of automation in the field of automation in the field of industry in the future. This is especially important, especially when practical learning in PLC programming differs from traditional learning methods. It involves expensive and limited equipment, safety issues that need to be solved, and extensive and ongoing training and skills requirements (Lim, 2002). The following question of study has been discussed in this research:

1. What is the need for a tool to teach programmable logic controller (PLC) for electrical motor installation course among students of a form 3 vocational school in Aceh, Indonesia?

2. How to develop a tool to teach programmable logic controller (PLC) for electrical motor installation courses among students of form 3 vocational school in Aceh, Indonesia?

\section{Literature Review}

The use of teaching aids in the teaching and learning process is absolutely necessary to understand what teachers are delivering [9]. Learning activities in technical schools are majority practical. Teachers are required to create learning environments that involve students to be motivated and seamless by determining appropriate strategies, approaches, models, media and learning techniques in order to achieve learning goals [27].

The use of media in the form of teaching aids is everything that explains the concept of learning from abstract or obscure material can be true and clear, thus developing students' thoughts, emotions, attention and interests, thus guiding students in the teaching and learning process [28].

From the relevance of the learning of the electrical motor control system, the delivery of all aspects of knowledge related to the development of the control system should be done especially for new users so that they can master the appropriate skills, the appropriate method for teaching this control system is to use teaching aids [22]. Isa [13] argues that teaching aid is one of the teaching aids used in the teaching and learning process that can help students understand the course content more effectively. The use of appropriate teaching aids has the potential to enhance academic competency and create different perceptions of how students benefit [19].

The various teaching aids available today are easily accessible, but less practical as they require considerable space to operate. This requires simpler aids to facilitate learning and teaching experiences. It is also necessary to ensure that the design of new aids is in line with industry standards as well as assisting in the learning process of teaching. In addition, laboratories are often an important component of technical education. However, factors such as limited laboratory hours, expensive equipment, and a high student ratio of equipment often impede student learning. Teaching aids can be used to help prepare students to make the most of limited laboratory resources [10]. 
There are many advantages to using good teaching aids to support PLC-based programming learning. This includes the possibility for students to learn on their own, since students can check their own calculations and understanding by incorporating appropriate programming systems into computer software and can further be simulated using teaching aids so that students have the opportunity to consider more realistic examples [3].

According to Ibrahim [11] the PLC teaching aids enable students to carry out various control strategies using microprocessor aimed at assisting learning activities in the laboratory as a complement to the theory of programming systems taught to students.

Programmable Logic Controller (PLC) is widely used in the manufacturing industry for automatization and becomes one of the important courses at the secondary and higher education levels. Studying theory in class alone is not enough to gain knowledge about PLC programming. Therefore, teaching aids are needed to assist in interactive learning in classes as well as live activities in the laboratory [25].

Meanwhile, Isa [13], stated that learning practices using PLC-based teaching aid for practical training in theoretical studies can help students better understand programming concepts, and can also effectively apply students' knowledge and experience in the teaching process. Burhan, Talib, \& Azman [4], in their study found that PLC teaching aids can improve direct skills aspects through circuit planning, installation and problem solving. From practical learning results in the laboratory, it was found that there was an increase in knowledge and skills directly as students used PLC teaching aids.

According to Mahadi et al. [15], in project-based learning, the use of PLC teaching aids is very important in improving the understanding and experience of students. Through this teaching aid, preliminary testing of the PLC control system can also be done in the actual laboratory. This can also save time in learning the PLC control system. In the $21^{\text {st }}$ century engineering teaching and learning process, PLCbased electrical and automation courses require the use of advanced techniques and learning aids to enhance students' understanding of everyday learning activities.

From the Gavali, Patil, \& Koli [8] research, the use of PLC teaching aids has found that student experience has increased to a considerable level through activities that allow students to collaborate and control PLC devices through collaboratively laboratory-oriented interactive tasks. In line with Sukir et al. [24] study which states that the effective use of PLC teaching aids in practical programming activities can effectively improve students' learning outcomes in cognitive, psychomotor, and affective aspects.

According to Ab Rahman et al. [26], the use of PLC teaching aids can form higher thinking ability to a certain extent, and can even deepen students' understanding of input and output circuit connectivity methods on motor control systems. With teaching aid suitable, teaching and activities become more effective as students gain real experience while developing PLC control systems similar to existing control systems in the industry. Hence, they also have the opportunity to work in groups to learn programming systems and improve communication skills, collaboration, idea sharing, learning ability, etc [21].

Khairudin et al. [14] in their study found differences in the competency level of students using PLC teaching aids. Students who do simulations with the help of PLC teaching aid have better interest and achievement in learning competencies compared to those who do not use the teaching aids in their learning activities. In line with study Yahaya, Mustafa, \& Ahad [29], found a positive effect on students using PLC teaching aids in their learning activities compared to students using conventional methods, they can be enthusiastic and want to learn the topic of PLC. Students are more focused and pay full attention when PLC teaching aids are exposed to the learning process. The use of PLC teaching aids is one of the teaching methods that has been proven to enhance students' competency. The diversity of approaches practiced by teachers such as the use of teaching aids is encouraged to make students more interested in the topic of the programming system and ultimately remove their negative response to the topic of the programming system.

According to Fatkhurohman \& Ratnanto Fitriadi [7], the use of PLC-based teaching aid is felt to be better and easier to learn especially for students who are just learning the industrial control system. Applying PLC programming with abstract and difficult staircase diagrams becomes easy to understand because it is simpler with the help of teaching aids. Furthermore, the use of teaching aid helps students to understand the correct wiring so as to avoid mistakes during operation.

Michal \& Peter Ján [16], argues the priority in utilizing the PLC teaching aids is to provide the practical experience and skills required as a programmer of the PLC. This kit also contributes to the 
creativity of students. Meanwhile, Perdana, Permata, \& Fatkhurrokhman [20] stated that the practice of using PLC teaching aids can significantly improve students' competencies. In addition, with the availability of such teaching aids, students can learn it more freely whether they are at school or at home. Therefore, it can be said that the use of PLC teaching aids has already facilitated and had a positive impact in programming learning, especially in technical and vocational schools in the field of electrical engineering. Based on the findings of past studies on the effects of using PLC teaching aids, researchers should conduct studies to develop PLC teaching aids that are easier to use at a higher cost more affordable and safe to use.

\section{Methodology}

This study was conducted to develop PLC teaching aids on electrical motor installation courses on PLC programming topics to assist teachers in providing an understanding of the concept of PLC culling. The context of this study is to provide easy-to-use teaching aids, safe to use and affordable aid construction costs to assist teachers in the implementation of the process teaching and practical learning.

The correspondents in this study are 3 expert teachers in electrical engineering at a vocational school in Aceh, Indonesia who evaluated the design and usability of the PLC teaching aids that have been developed.

\section{Experiment Design}

The study used an expansion method with the ADDIE model. This research is carried out to study the exact condition of the object, and there is no need to test any specific hypothesis. PLC teaching aids need to be developed to achieve research objectives. The PLC teaching aids developed consist of two stages, namely hardware and software development. PLC teaching aid hardware is an arrangement of several components connected through electrical wiring while software is an application used for programming that allows teaching aids to work and be used according to the needs of users. The software used is the $C X$-Programmer which contains the plc and $C X$-Designer programming languages that serve as a design application in the Human Machine Interface through the help of computers.

In this study, the ADDIE model was chosen as a guide for researchers to develop teaching aids systematically according to regular processes. ADDIE is an acronym for describing the main sections and steps to follow, namely analysis, design, development, implementation and evaluation. The development process of the teaching aids in this study involves five phases, namely the process of analyzing at an early stage, the process of designing teaching aids, developing teaching aids and planning activities, and finally the testing and evaluation process of the entire teaching aid. This model was chosen because it emphasizes repetition for each phase. Each phase is also connected to each other. If the phase cannot be properly implemented, the process can be repeated until it is completed.

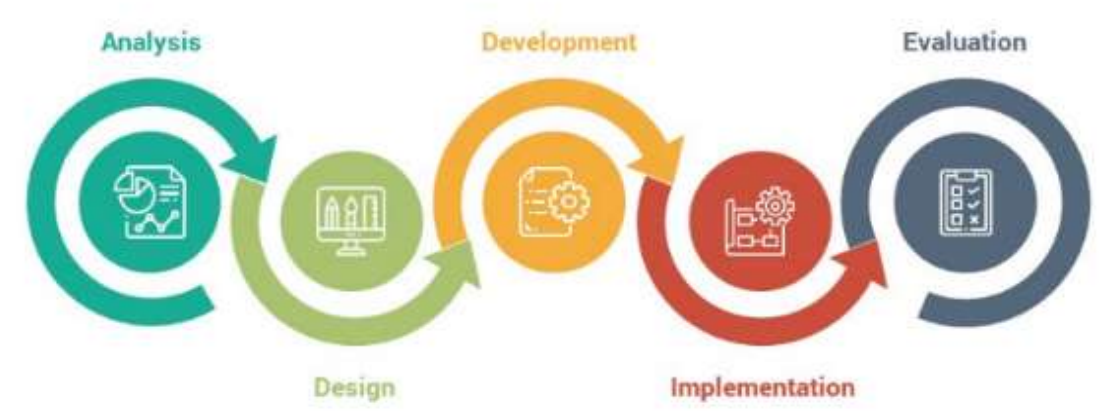

Figure 2 - ADDIE model

The ADDIE model has been absorbed in the development of logic control programming (PLC) teaching aids consisting of phases of analysis, design, development, implementation and evaluation (Figure 2). The educational philosophy that needs to be applied when the ADDIE model is used is that the learning 
process needs to be student-centered, innovative and inspiring for students [17]. The ADDIE model can be used to produce effective teaching aids, especially technological aids.

\section{Results}

\section{Finding and discussion}

Research Question 1: What is the need for a tool to teach programmable logic controller (PLC) for an electrical motor installation course among students of form 3 vocational school in Aceh, Indonesia?

Analysis of the need to develop a product to ensure that the product is built to meet the needs of consumers. This study was conducted to analyze the needs and specifications of the teaching aids in PLC programming on the electrical motor installation course among students of form 3 vocational school. Analysis of the development needs of PLC teaching aids based on the views of expert teachers during pilot studies, where there are various problems faced by teachers and students in the teaching and learning process on the Electrical Motor Installation course on the topic of PLC programming, specifically in form 3 students vocational school. Researchers conduct interviews on expert teachers to identify problems in learning and obtain insights for the importance of developing PLC teaching aids.

Teacher expert $1^{\text {st }}$ provides insight on problems in learning hands on electrical motor installation, students only do conventional learning, i.e. simple connection of wiring motor. This causes students not to understand the methods of control of electrical motor using complex coding and software.

Teacher expert $2^{\text {nd }}$ also emphasizes the problems in learning the PLC programming-based electrical motor installation course. Students do not understand the basic knowledge of PLC programming and motor control due to poor teacher learning. Unfortunately, the lack of teachers' understanding of the field has made PLC teaching aid difficult to produce. Furthermore, the cost of expensive ones makes providing PLC teaching aids difficult to do.

This was agreed by teacher expert $3^{\text {rd }}$ by saying that the lack of stakeholders' attention regarding the provision of teaching aids, resulting in less effective learning activities because the existing PLC teaching aids do not correspond to the total number of students.

Based on the views of the expert teachers, the above is the basis for the development of PLC teaching aids that can be used by teachers and students to support the practical learning process. The provision of PLC teaching aids developed must be able to solve the problems that arise, namely by producing PLC teaching aids at a low cost, easy to use and stimulating student interest and improving the achievement of learning outcomes.

To overcome learning problems in the electrical motor installation course, the development of PLC teaching aids was developed based on the views of experts during the pilot study. To produce products that are suitable to the needs of consumers, a development model is used as a formwork so that the development process meets the right procedures and methods. The ADDIE model was chosen as the model in this study because it is considered the most suitable.

The ADDIE model comprises five phases of analysis phase, design phase, development phase, implementation phase and evaluation phase. This model is one of the systematic teaching design models in the production of effective and user-friendly computerized learning materials [2].

The analysis phase in the process of learning aid development is to identify problems and analyze the needs of teaching aids in learning. This is to ensure that the learning aids developed can meet the needs of real users. To identify this requirement, a pilot study was conducted on the installation of electric motor based on PLC technology and found that students had difficulty in understanding the learning due to technical complexity and principles. Students also cannot see the application of logical control programming operations on the installation system of the electrical motor itself. In this study, researchers focused more on discussing ADDIE development models as references in developing tools to teach PLC.

Research Question 2: How to develop a tool teaching programmable logic controller (PLC) for electrical motor installation courses among students of form 3 vocational school in Aceh, Indonesia? 
The ADDIE model adapts inputs, processes and outputs as a way to complete all phases [6]. Inputs will respond with known variables through the receipt of data, information and knowledge [5]. The input level in this study is through the need for data, information and knowledge based on the response from the respondents during the study.

The process is seen as a way to stimulate creative thinking in using procedures, translating and explaining various approaches that can be used in the learning process [5]. In the process stages include a design process which is a systematic method of planning, developing, evaluating and managing the learning and development process that refers to the tools used to create learning materials. The purpose of this phase is to produce and verify learning resources. Once the design and development process is completed, then the next process is the implementation process. The purpose of this implementation phase is to provide a society to help teach learning lessons that can accommodate the learning process that has been developed. This phase also includes preparing students and teachers involved in the learning process.

Output sends results from process phases in appropriate action [17]. The output part is the evaluation process. The purpose of the evaluation phase is to evaluate the quality of the product and the learning process before and after the implementation process. The usual procedure in the evaluation phase is to determine the evaluation criteria, select or develop the assessment tool and subsequently perform the assessment. A common component of the evaluation phase is collecting and analyzing data related to the criteria to be evaluated. The study has three evaluation criteria namely achievement, $21^{\text {st }}$ century skills and motivation of students towards teaching materials. The achievement criteria are chosen by the researchers because the achievement will show the researchers the extent to which the impact of teaching aids based on PLC can impact students' understanding and achievement of students' competency courses on PLC programming topics.

The results of a study conducted by Razak \& Rahman [23] show that teaching aids developed by them using the ADDIE model managed to have a positive impact as an additional learning tool. Mukhari \& Naharuddin [18] also applied ADDIE design models in the development of their teaching aids. The results of testing the teaching aids found that they meet the features of interactive multimedia and meet the objectives set. The same goes for the study conducted by Zakaria \& Rahman [31]. The ADDIE model used successfully attracts students to the teaching and learning process.

\section{Analysis}

According to Branch [5] there are several steps in the phase of needs analysis which are to confirm the existence of achievement gaps, determine teaching goals, ensure the needs of consumers, identify the necessary resources in the next development process and prepare a project management plan.

Need analysis was also carried out with the aim of looking at the issues and problems of learning the electrical motor installation course on the topic of PLC students of form 3 vocational school in Aceh, Indonesia area which led to the need for the development of media teaching aids PLC. The use of media and learning resources is an influential component of the learning process. Learning media in this context is a technology and/or a set of tools that carry material content messages that can be used for learning needs.

\section{Design}

Kit Design. PLC teaching aids are designed in two stages, namely hardware design and electrical design. PLC teaching aid is designed using the 2010 version of Auto cad software. The software used to draw or design 2D and 3D objects. Auto cad is a CAD (Computer Aided Drafting) based software that is widely used because it has many advantages over other products with the same functionality. Usually this is used by civil engineers, electricians, machinery and some other similar jobs. The researchers chose this software to design PLC teaching aid because it is of high quality and can be made resembling original shapes. Researchers can also adjust the size of the design results. The software is able to produce design drawings with high precision, easy and with very efficient time. Figure 3 shows the design of the hardware of the PLC teaching aids. 


\section{Electrical Design}

To design electrical circuit wiring, researchers adapted to existing components and materials. The design of the electrical circuit wiring of PLC teaching aids is also designed using Auto cad software. Figure 4 is a block diagram of PLC teaching aid system.

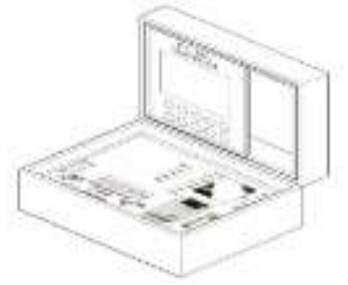

(a)

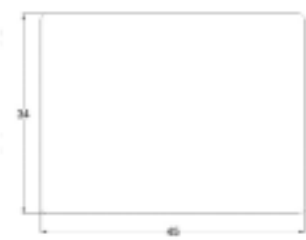

(b)

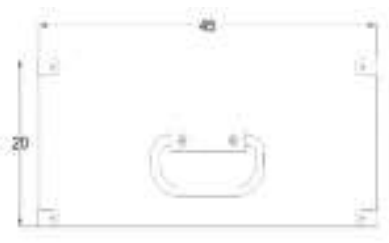

(c)

Figure 3 - (a) 3D design of PLC teaching aids, (b) sketch views on PLC teaching aids, (c) sketch of the front view of the PLC teaching aids

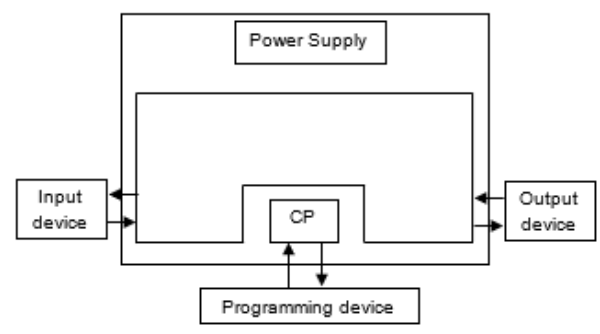

Figure 4 - PLC teaching aid block diagram

According to Figure 4 above, the PLC teaching aid block diagram consists of an input component consisting of a push button. The PLC programming device in the study used the PLC Omron CPM1A which has 20 terminals that can be used as an addressing of input and output components represented with numeric codes 00 to 11 which facilitate programmers when designing and building electrical machine programming designs. Power supply works to drain the electric current for components that require direct current (DC). The electric current that goes into the power supply of the shuttle current 220VAC is transformed into a direct current of 24VDC. While the output device consists of indicator lights, electric motors etc. The PLC teaching aids are also multiplied by the Inverter Schneider electric motor speed regulator device atV12H075M2, potentiometer and human interface device HMI Omron NS5 Series.

\section{Development}

Physical Development. The development of PLC learning aids consists of two activities, namely physical development and software development. The development of PLC teaching aids is structured from electrical components that are interconnected with each other. Wooden boxes are used as a place to place the components of teaching aids. Wood material is chosen because wood is a material that cannot transmit electric current until it is felt safer for use.

As for the planning and construction work, PLC teaching aid does not escape the use of tools and materials that facilitate researchers in completing a job. The tools and materials used consist of: 1) Jigsaw machine used for cutting acrylic material; 2) saw machine for cutting wood material; 3) drill machine sits to perforate acrylic material; 4) wood crab machine to smooth the surface of wood; 5) meters to measure the needs of wood and acrylic materials; 6 ) hammer used to punch objects, so that the object is firmly glued, where normally the beaten object is nails; 7) nails 1,5 " for the hardening of the sides of the wood material to be stronger; 8) screwdriver useful for twisting the screws; 9) screws used to glue parts of again of wood material and components; 10) HPL adhesives to coat the surface of wood; and 11) glue wood to glue the sides of wood material and HPL adhesives on wooden surfaces. Table 1 details the requirements of the components used in the construction work of the PLC teaching aids. 
Table 1 - Components of the teaching aids

\begin{tabular}{|c|l|l|c|}
\hline No & \multicolumn{1}{|c|}{ Materials } & \multicolumn{1}{|c|}{ Specifications } & Total \\
\hline 1 & Kit box & Wood 45x35x20 & 1 Unit \\
\hline 2 & Acrylic & Marga Cipta, 3 mm white & $1 / 2$ Meter \\
\hline 3 & MCB 1 phase & Visalux VS-106, 6A, 230/400 V 50Hz & 1 Unit \\
\hline 4 & HMI & Omron NS5 Series & 1 Unit \\
\hline 5 & PLC & Omron CPM1A, 20CDR-A-V1 & 1 Unit \\
\hline 6 & Inverter Altivar Schneider & $\begin{array}{l}\text { Schneider, ATV12H075M2, SYS Drive } \\
\text { 3GJV, 0.75kW, 1HP, 200, 240V }\end{array}$ & 1 Unit \\
\hline 7 & & DP177.101, 24V/10A DC & 1 Pcs \\
\hline 8 & Banana plug (+) & Standard & 10 Pairs \\
\hline 9 & Jack Banana Plug (-) & Red/Black/Yellow & 41 Pcs \\
\hline 10 & Push button & NO/NC & Pcs \\
\hline 11 & Indicator Lamp & Red, Green, Yellow & 1 Pcs \\
\hline 12 & Potentiometer & $100 k$ S & 2 Pcs \\
\hline 13 & Bush bar & 12 Terminal & 1 Set \\
\hline 14 & Port PLC Cable & Omron RS232 & Set \\
\hline 15 & PLC-HMl communication cable & Omron RS232 \\
\hline 16 & Connecting cable & ITS 1.5 mm red/blue/black color \\
\hline
\end{tabular}

The stage of development of the PLC teaching aid is to make box measurements in accordance with the sketch design of the previously made product. Next, the wood material is cut in size using a machine and glues parts of wood material that have been cut using glue and nails. Figure 5 is the activity of building wooden boxes of PLC teaching aid.

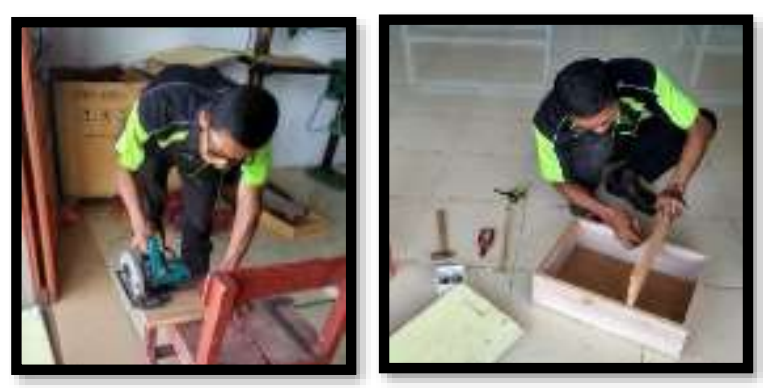

Figure 5 - PLC teaching aid box development

Subsequently, after the teaching aid box was completed, researchers installed an HPL sticker to provide an attractive look at the teaching aid box and installed corner plates to provide security to users and the PLC teaching aid boxes. Figure 6 is the look of boxes before and after installing HPL stickers.

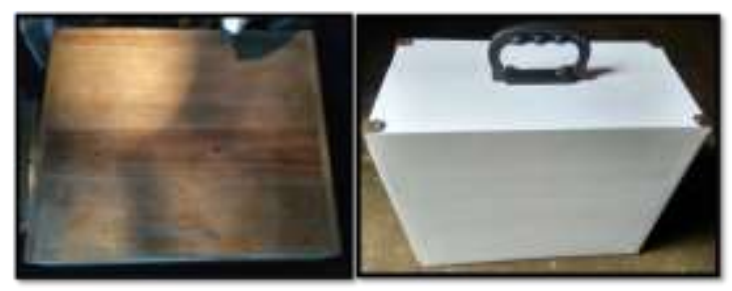

(a)

(b)

Figure 6 - (a) The look of the box that has not been sticker; (b) the look of the box that has been given stickers

Further stages are by perforating the surface of acrylic materials as the placeholders of key components such as PLC, HMI and Inverter components, as well as input components such as press buttons and output components such as indicator lights and electrical circuit wiring points. Figure 7 shows the perforated activity of perforated acrylic materials using drill machines. 
Figure 8 shows the activity of installing electrical circuit wiring. The installation of electrical circuit wire is done by connecting the cables to the component terminals as well as connecting the output from each of the components to the banana ignition plate by way of being pecked. The relationship of electrical circuit wiring between components and ignition is a reference to previously planned electrical designs.

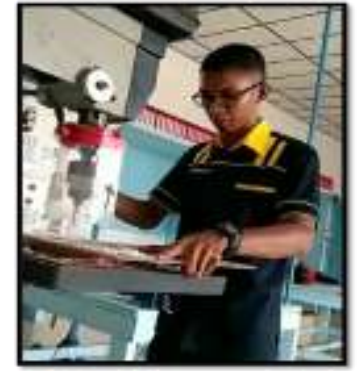

Figure 7 - Acrylic drilling activities

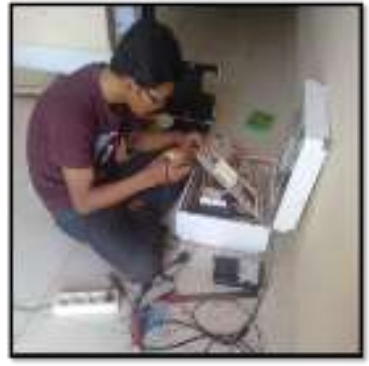

Figure 8 - Soldering of electrical circuits to PLC teaching aid components

Figure 9 of the PLC teaching aids that have been developed. Once the PLC teaching aids have been developed, the next stage is to design the programming system in CX-Programmer software and face-toface design of the electrical machine control system in the $C X$-Designer software so that it can be applied to the kit.

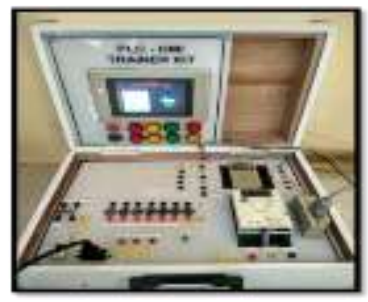

Figure 9 - PLC teaching aid display

Software Development. The CX-Programmer software is a software used to create PLC programming systems from the Omron brand. The software is also used for testing of the PLC programming work system before being transferred to the PLC device. The CX-Designer software can be used as a simulation that is featured face-to-face on HMI devices and can be combined with the CX-Programmer software. To be able to use both of these softwares, the user first installs into the computer system. Besides, users also need to configure the computer system with PLC and HMI devices. Figure 10 is Omron's CX-One software.

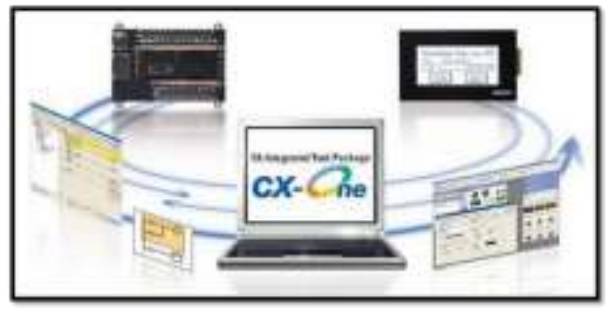

Figure 10 - Computer software for PLC and HMI programming

\section{Evaluation}

The development of PLC teaching aid was carried out by conducting several assessments on the delegate group. There are three stages to go through and verification on PLC teaching aid is the following:

- First stage: Pilot Study

- Second stage: Expert Evaluation

- Third stage: Use of teaching aid 
Based on commented by the $1^{\text {st }}$ expert, the PLC teaching aid developed has a suitable size until the compilation of neat and neat components in the box. In addition, the PLC teaching aid also has a circuit protector so that the electrical terminal is not exposed until it is safer to use.

Expert 2 gives the view that the PLC teaching aids that have been developed have relatively affordable construction costs due to the use of medium and readily available materials in the environment. The teaching aids are also sturdy and protect students against electrical shocks.

According to experts 3, PLC teaching aids are developed in a portable form thus facilitating mobility in practical learning. In addition, the PLC teaching aid has also been equipped with a manual of use and is equipped with circuit protectors and plug-in components. According to Intan [12], the effect of using teaching aids with plug and unplug systems is higher compared to using conventional wiring systems. In line with a study conducted by Zahri \& Osman [30], they argue that teaching aids that use plug-in components make it easier for students to process circuits for understanding purposes. The use of teaching aids can also increase the level of understanding of students and thus improve the number of scores obtained [32]. In addition, the amount of time in practical activities can also be reduced and thus provides an opportunity for students to try practically repeatedly. This teaching aid can also make it easier for teachers to stage demonstrations and in turn spark students' interest in practical practice in the laboratory.

\section{Conclusion}

This study was conducted to develop PLC teaching aids in electrical machine assembly courses. Based on the findings, the respondents strongly agreed that PLC teaching aids are suitable and safe for students to use in the learning process. For its very simple operation, users only need to connect the electrical circuit from teaching aids to the input and output components of the block terminals that are already available. In addition, PLC teaching aids can save time in delivering learning content and make it easier for teachers to control students in the classroom. Interesting and creative teaching aids can usually attract and focus students on the learning process. The development of PLC teaching aids is one of the efforts to improve students' knowledge and understanding in learning PLC topics. Through these teaching aids, teachers can reveal the concept of automation and PLC programming either theoretically or practically become more effective. Overall, PLC teaching aids have a positive impact on learning.

This study provides a clear picture that the use of appropriate teaching aids can help students to obtain better learning outcomes in the competency of electric motor installation course on the topic of PLC programming. This study has also produced teaching aids that are cheap, easy to use, safe and can stimulate students' interest in learning. Through this study, it is hoped that teachers can pay attention to the provision of creative and innovative and affordable teaching aids to produce an effective learning. The proposed advanced study is to test the impact of these teaching aids on student achievement in electrical machine assembly courses.

Conflicts of interest. On behalf of all authors, the corresponding author states that there is no conflict of interest.

Acknowledgment. The authors would like to thank Aceh Government and Aceh Human Resources Development (BPSDMA) for providing financial support under fund grant peg.826.1/023/2019.

Cite this article as: Pratama, H.; Azman, M.N.A.; Zakaria, N.A.; Khairudin, M. (2021). Development of programmable logic controller teaching aids on electrical motor installation course among vocational school students in Aceh, Indonesia. Challenges of Science. Issue IV, pp. 117-127. https://doi.org/10.31643/2021.19

\section{References}

[1] Said, H., (2012). Aplikasi Programmable Logic Controller (PLC) dan Sistem Pneumatik pada Manufaktur Industri. Yogyakarta: C.V Andi Offset.

[2] Aris, B. (2002). Reka bentuk perisian multimedia. Penerbit UTM.

[3] Atherton, D. P. (1998). Teaching classical design using the control teaching kit. Measurement and Control, 31(5), 143-146. 


\section{Materials of International Practical Internet Conference “Challenges of Science”, Issue IV, 2021}

[4] Burhan, I., Talib, S., \& Azman, A. A. (2012). "Design and fabrication of Programmable Logic Controller teaching kit with multiple output module for teaching and learning purposes," 2012 IEEE 8th International Colloquium on Signal Processing and its Applications, pp. 14-18, doi: 10.1109/CSPA.2012.6194681.

[5] Branch, R. M. (2009). Instructional design: The ADDIE approach (Vol. 722). USA: Springer Science \& Business Media.

[6] Dick, W., \& Carey, L. (2004). The Systematic Design of Instruction. Allyn \& Bacon; 6th ed. https://www.kroobannok.com/35953.

[7] Fatkhurohman, M. I., \& Ratnanto Fitriadi, S. T. (2020). Pembuatan Modul Trainer Alat bantu mengajar Material Handling Crane Menggunakan PLC Omron (Doctoral dissertation, Universitas Muhammadiyah Surakarta).

[8] Gavali, A. B., Patil, S. A., \& Koli, A. R. (2016). "Technology-Based Learning system in Programmable Logic Controller Education," 2016 IEEE Eighth International Conference on Technology for Education (T4E), pp. 264-265, doi: 10.1109/T4E.2016.071

[9] Hussin, M. S. (2000). Kajian Terhadap Kepentingan Penggunaan Alat Bantu Mengajar Di Sekolah Menengah Teknik (Doctoral dissertation, Universiti Teknologi Malaysia).

[10] Hsieh, S. (2005, June), Design of Web Based Ladder Logic Tool teaching kit for Programmable Logic Controller Education Paper presented at 2005 Annual Conference, Portland, Oregon. 10.18260/1-2-15345.

[11] Ibrahim, D. (2003). Teaching digital control using a low-cost microcontroller-based temperature control teaching kit. International Journal of Electrical Engineering Education, 40(3), 175-187.

[12] Intan, R. P. (2018) Analisis Perbandingan Penggunaan Media Pembelajaran Sistem Wiring Dan Sistem Plug Unplug Terhadap Hasil Belajar Siswa Pada Mata Pelajaran Teknik Kontrol Pokok Bahasan Programmable Logic Controller (PLC) Di Smk Negeri 2 Cimahi. S1 thesis, Universitas Pendidikan Indonesia.

[13] Isa, N. R. M. (2012). Kesan penggunaan educational multifunctional programmable logic controller kit terhadap pencapaian pelajar yang berbeza gaya kognitif (Doctoral dissertation, Universiti Tun Hussein Onn Malaysia).

[14] Khairudin, A. R. M., Abu-Samah, A., Aziz, N. A. S., Azlan, M. A. F. M., Karim, M. H. A., \& Zian, N. M. (2019). "Design of Portable Industrial Automation Education Training Alat bantu mengajar Compatible for IR 4.0," 2019 IEEE 7th Conference on Systems, Process and Control (ICSPC), 2019, pp. 38-42, doi: 10.1109/ICSPC47137.2019.9068090.

[15] Mahadi, M., Amin, M., Amri, N., Ab Rahim, M., \& Majid, A. (2015). PLC Trainer Alat bantu mengajar Simulator: An Improvement for Automation Study in Polimas. In Applied Mechanics and Materials (Vol. 786, pp. 367-371). Trans Tech Publications Ltd.

[16] Michal, K., \& Peter Ján, S. (2021). Training stands of programmable logic controllers for educational purposes. Technical sciences and technologies, (3 (21), 274-280.

[17] Morrison, G. R., \& Lowther, D. L. (2010). Educational technology research past and present: Balancing rigor and relevance to impact school learning. Contemporary educational technology, 1(1), 17-35.

[18] Mukhari, A. W., \& Naharuddin, M. F. (2011). Membangunkan Perisian Multimedia Interaktif Teknologi Automotif: Anti-Lock Brake System (ABS). Journal of Technical, Vocational \& Engineering Education, 4, 38-57.

[19] Ng, Y. S., \& Tan, S. Y. (2004). Amalan Penggunaan Alat Bantu Mengajar (abm) di Kalangan Guru-guru Teknikal sekolah Menengah Teknik, negeri Kedah. Bachelor's thesis, Universiti Teknologi Malaysia.

[20] Perdana, G., Permata, E., \& Fatkhurrokhman, M. (2021). Development of Learning Media Programmable Logic Control on Electric Motor Installation Courses in Smkn 2 City of Serang. Jurnal Pendidikan Teknologi Informasi dan Vokasional, 3(1).

[21] Pratama, H. (2018). Pengembangan Trainer Pengontrolan Elektromagnetik Pada Jurusan Teknik Instalasi Tenaga Listrik Di Smk Negeri 2 Peureulak Aceh Timur. CIRCUIT: Jurnal Ilmiah Pendidikan Teknik Elektro, 2(1).

[22] Rahayu, N. S. (2019) Pengawalan peralatan elektrik dan keselamatan di sekolah ke arah bercirikan revolusi industri 4.0. Master's thesis, Universiti Tun Hussein Onn Malaysia.

[23] Razak, R. A., \& Rahman, M. A. (2017). Pembinaan media pengajaran berasaskan multimedia di kalangan guru ICTL. JuKu: Jurnal Kurikulum \& Pengajaran Asia Pasifik, 1(2), 20-31.

[24] Sukir, S., Soenarto, S., \& Soeharto, S. (2017). Developing conveyor trainer kit for programmable logic controllers in practical learning. Jurnal Pendidikan Vokasi, 7(3), 329-339.

[25] Thamrin, N. M., \& Ismail, M. M. (2011). "Development of virtual machine for Programmable Logic Controller (PLC) by using STEPS ${ }^{\mathrm{TM}}$ programming method," 2011 IEEE International Conference on System Engineering and Technology, pp. 138-142, doi: 10.1109/ICSEngT.2011.5993437.

[26] Ab Rahman, A., Zolkifly, N. A., Hanafi, N. M., \& Yusof, A. M. (2018). Kompetensi Pelajar Membina Pengaturcaraan Kawalan Logik (Plc) Bagi Kursus Automasi Industri Di Kolej Vokasional. Online Journal for TVET Practitioners, 3(2).

[27] Vajarintarangoon, K., Bunkanan, P., Deelon, S., Poldech, S., \& Thauyngam, K. (2019). The Development Process PLC Competencies for School Administrators in Buriram Province. International Education Studies, 12(6), 148-154.

[28] Wena, M. (2010). Strategi Pembelajaran Inovatif Kontemporer. Penerbit Bumi Aksara, Jakarta.

[29] Yahaya, M. H. B., Mustafa, M. Z. B., \& Ahad, R. B. (2019). The Effectiveness of Programmable Logic Controller Teaching Aids for Control System Module in Vocational College. Universal Journal of Educational Research, 7(12A), 51-59.

[30] Zahri, A. B. M., \& Osman, M. I. B. (2019). Kit Pembelajaran Litar Siri, Selari Dan Siri-Selari. Journal on Technical and Vocational Education, 4(1), 15-22.

[31] Zakaria, M. A. Z. M., \& Rahman, N. S. A. (2010). Pembangunan Perisian Pembelajaran Berbantukan Komputer (PBK) Bagi Topik Bulatan Matematik Tingkatan 2 Berasaskan Teori Konstruktivisme.

[32] Pratama H., Azman M.N.A., Kenzhaliyev O.B., Wijaya H., Kassymova G.K. (2021). Application of augmented reality technology as an interactive learning medium in geography subjects. News of the National Academy of Sciences of the Republic of Kazakhstan, Series of Geology and Technical Sciences. Volume 4, Number 448, 21-29 https://doi.org/10.32014/2021.2518170X.77 